\title{
ANALISIS PERBEDAAN RELEVANSI NILAI DARI NILAI BUKU EKUITAS DAN LABA PER LEMBAR SAHAM TERHADAP HARGA SAHAM PADA PERIODE SEBELUM DAN SESUDAH PENERAPAN SAK BERBASIS IFRS
}

\author{
Panubut Simorangkir \\ Perbanas Institut Jakarta \\ panubut@perbanas.id
}

\begin{abstract}
This study was conducted to examine whether the implementation of GAAP-IFRS based results of any difference relevance of equity book value and share earnings, using the market price of the stock as the dependent variable, the equity book value and share earnings as an independent variable, and the periods before and after the application of GAAP-based IFRS. The analysis uses panel data regression analysis with random effects models. This research was conducted on 51 manufacturer companies listed on the Stock Exchange the period prior to the application of IFRS-based IFRSs 2008-2010 and after the application of GAAP-IFRS based in 2012-2014. The study found that in the period of after the implementation of GAAPIFRS based the relevance of equity book value increased against the market price of the shares, while the relevance of share earnings experienced a significant decrease in stock market prices.
\end{abstract}

Keywords: Relevance values, stock prices, the book value of equity, share earnings, GAAP, IFRS.

\section{PENDAhUluan}

\subsection{Latar Belakang}

Indonesia melakukan konvergensi Standar Akuntansi Keuangan (SAK) dengan IFRS tahun 2008, tepatnya saat Indonesia menyatakannya di dalam pertemuan G-20. Konvergensi SAK dengan IFRS dilakukan secara bertahap dengan target penerapan penuh IFRS pada SAK dapat diselesaikan pada tahun 2012 (Suprihatin dan Tresnaningsih, 2013).

Kewajiban menggunakan IFRS bagi entitas yang terdaftar di bursa efek merupakan perubahan paling signifikan dalam sejarah regulasi akuntansi (Daske dkk., 2008). Konvergensi SAK dengan IFRS diharapkan meningkatkan fungsi pasar modal global dengan menyediakan informasi yang lebih dapat diperbandingkan dan berkualitas tinggi kepada investor (Barth, 2008). Selain itu IFRS juga diharapkan dapat memberikan informasi keuangan yang lebih akurat, komprehensif, dan tepat waktu dibandingkan standar akuntansi nasional yang banyak dipengaruhi oleh hukum negara, politik, dan perpajakan di negara tersebut (Ball, 2006).

Penerapan IFRS diklaim akan meningkatkan kualitas laporan keuangan dan kemampuan informasi akuntansi dalam mengestimasi harga saham, yang dikenal dengan studi relevansi nilai (value relevance) (Suprihatin dan Tresnaningsih, 2013). Kargin (2013) menyatakan bahwa relevansi nilai adalah kemampuan informasi yang disajikan dalam laporan keuangan untuk menangkap dan menyimpulkan nilai perusahaan. Relevansi nilai dapat diukur dengan mengestimasi hubungan statistik antara informasi yang disajikan dalam laporan keuangan dengan nilai saham di pasar.

Berbagai penelitian sebelumnya tentang relevansi nilai yang menggunakan model Ohlson (1995) menyatakan bahwa terdapat peningkatan hubungan antara harga pasar saham dengan 
nilai buku ekuitas dan laba per saham (Iatridis, 2010; Chalmers, Clinch, dan Godfrey, 2011; Kargin 2013) setelah penerapan IFRS tetapi dengan hasil yang berbeda-beda. Iatridis (2010) menemukan bahwa pada periode setelah adopsi IFRS terdapat peningkatan relevansi nilai dari nilai buku ekuitas dan laba per saham terhadap harga pasar saham pada perusahaan yang tercatat di Bursa Efek London. Sementara Kargin (2013) menemukan bahwa setelah penerapan IFRS terdapat peningkatan relevansi nilai dari nilai buku ekuitas, namun tidak ada peningkatan relevansi nilai atas laba per saham pada perusahaan yang terdaftar di Bursa Efek Istanbul selama tahun 1998-2011. Chalmers, Clinch, dan Godfrey (2011) menemukan hasil yang berbeda, bahwa setelah penerapan IFRS terdapat peningkatan relevansi nilai terhadap laba per saham, sementara relevansi nilai dari nilai buku ekuitas tidak ada peningkatan pada perusahaan yang terdaftar di Australian Securities Exchange selama tahun 1990-2008.

Hasil penelitian Khanagha (2011) menunjukkan bahwa relevansi nilai laba dan nilai buku ekuitas mengalami penurunan setelah periode penerapan IFRS pada perusahaan yang tercatat di pasar saham Uni Emirat Arab. Hasil serupa ditemukan oleh Callao, Jarne dan Lainez (2007) yang menemukan bahwa relevansi nilai laba dan nilai buku ekuitas tidak mengalami perubahan yang signifikan dalam jangka pendek pada perusahaan yang terdaftar di IBEX 35 (35 saham paling likuid di Bursa Efek Madrid).

Penelitian tentang peningkatan relevansi nilai setelah penerapan IFRS pada perusahaan yang terdaftar di BEI juga menemukan hasil yang berbeda-beda. Rohmah dan Yuni (2013) menyimpulkan bahwa relevansi nilai laba dan nilai buku ekuitas akan meningkat setelah adopsi IFRS. Sementara Suprihatin dan Tresnaningsih (2013) menyatakan bahwa pada awal penerapan IFRS laba per saham mengalami peningkatan dalam relevansi nilai, sedangkan nilai buku ekuitas tidak meningkat. Tetapi pada tahap lanjut penerapan IFRS, relevansi nilai untuk laba per saham dan nilai buku ekuitas mengalami peningkatan. Cahyonowati dan Ratmono (2012) menyatakan bahwa tidak terdapat peningkatan relevansi nilai laba dan nilai buku ekuitas secara keseluruhan setelah periode adopsi IFRS.

Menurut Suprihatin dan Tresnaningsih (2013), penerapan IFRS diklaim akan meningkatkan kualitas laporan keuangan. Berdasarkan pernyataan tersebut dan adanya hasil penelitian di Indonesia yang berbeda-beda yang telah dijelaskan sebelumnya, mendorong dilakukannya penelitian untuk menguji apakah penerapan SAK berbasis IFRS telah meningkatkan relevansi nilai laba dan nilai buku ekuitas pada perusahaan manufaktur yang terdaftar di BEI. Relevansi nilai dalam penelitian ini difokuskan pada harga pasar saham, dimana harga pasar saham dapat dilihat dari laba per saham dan nilai buku ekuitas.

Berdasarkan permasalahan yang sudah dijelaskan di atas, penelitian ini dilakukan dengan judul "Analisis Perbedaan Relevansi Nilai dari Nilai Buku Ekuitas dan Laba Per Saham terhadap Harga Saham pada Periode Sebelum dan Sesudah Penerapan SAK Berbasis IFRS".

\subsection{Perumusan Masalah}

Berdasarkan identifikasi masalah yang dikemukakan di atas, maka rumusan masalah yang akan dibahas dalam penelitian ini adalah sebagai berikut:

a. Apakah terdapat perbedaan relevansi nilai dari nilai buku ekuitas terhadap harga saham pada periode sebelum dan sesudah penerapan SAK berbasis IFRS?

b. Apakah terdapat perbedaan relevansi nilai dari laba per saham terhadap harga saham pada periode sebelum dan sesudah penerapan SAK berbasis IFRS?

\section{TINJAUAN PUSTAKA DAN PERUMUSAN HIPOTESIS}

\subsection{Teori Surplus Bersih (Clean Surplus Theory)}

Menurut Ohlson (1995), perubahan nilai buku ekuitas sama dengan laba dikurangi dividen atau sama dengan net of capital contribution. Hubungan inilah yang disebut dengan clean surplus. Teori ini menyatakan bahwa nilai perusahaan tercermin pada informasi akuntansi dalam laporan keuangan. Penelitian relevansi nilai dirancang untuk menetapkan manfaat informasi akuntansi terhadap pernilaian ekuitas perusahaan. Konsep relevansi nilai tidak 
terlepas dari kriteria relevan dalam standar akuntansi keuangan, karena jumlah suatu angka akuntansi akan relevan jika jumlah yang disajikan merefleksikan informasi yang relevan dengan penilaian suatu perusahaan (Widiastuti dan Meiden, 2013).

Menurut Mackenzie dkk. (2014: 31), konsep relevansi nilai berkaitan dengan suatu aspek informasi yang mempunyai kemampuan untuk mempengaruhi keputusan investor, kreditor dan pemakai laporan keuangan lainnya. Teori clean surplus menyediakan suatu kerangka yang konsisten dengan pengukuran yang menunjukkan bahwa nilai pasar tercermin dalam laporan keuangan yaitu neraca dan laporan laba rugi.

Model penilaian Francis dan Schipper (1999) menghubungkan secara langsung kemampuan prediksi yang mendasari relevansi nilai dan nilai pasar yang diproksikan sebagai harga dan return saham. Nilai pasar perusahaan dapat dipahami sebagai laba agregasi perusahaan yang diharapkan di masa yang akan datang. Laba yang diharapkan di masa yang akan datang tersebut akan memberikan informasi yang cukup untuk menghitung present value dalam penilaian suatu perusahaan (Ohlson, 1995).

\section{Teori Agensi}

Menurut Jensen dan Meckling (1976), hubungan keagenan adalah sebuah kontrak antara satu atau lebih orang (principals) dengan mengikutsertakan orang lain (agent) untuk memberikan jasa atas nama mereka yang melibatkan pendelegasian beberapa wewenang pengambilan keputusan kepada agen. Prinsipal membayar agen dengan menyerahkan sumber daya (bonding cost) untuk menjamin bahwa agen tidak akan melakukan tindakan yang merugikan principal. Perbedaan kepentingan antara prinsipal dan agen dalam teori agensi akan menimbulkan asimetri informasi, yaitu di mana manajer mempunyai informasi yang lebih dibandingkan dengan prinsipal. Prinsipal dapat menilai kinerja manajer dengan menggunakan suatu alat ukur yaitu laporan keuangan yang harus full disclosure sehingga prinsipal benar dalam mengambil keputusan dan kualitas informasi akuntansi dapat dipertanggungjawabkan (Scott, 2009: 1-18).

Salah satu alat yang dapat digunakan untuk menilai kinerja agen adalah harga saham. Harga saham yang meningkat mengindikasikan bahwa kinerja perusahaan dalam hal ini adalah manajer juga meningkat. Sedangkan naik turunnya harga saham dipengaruhi oleh informasi yang terdapat dalam laporan keuangan perusahaan (Wulandari, 2014).

\subsection{Relevansi Nilai}

Relevansi nilai menjadi bidang penelitian yang banyak dilakukan sejak diperkenalkan oleh Ohlson (1995) dan didukung oleh Bernard (1995). Menurut Ohlson (1995), variabel laba memiliki relevansi nilai karena memiliki hubungan statistik dengan harga saham yang mencerminkan nilai perusahaan. Relevansi nilai menunjukkan seberapa baik informasi laba dapat mempresentasikan informasi yang digunakan oleh pengguna dalam menilai perusahaan. Akuntansi keuangan tidak didesain secara langsung untuk mengukur nilai suatu perusahaan, tetapi informasi yang terkandung dalam laporan keuangan dapat membantu pengguna laporan keuangan untuk menilai suatu perusahaan (Bae dan Jeong, 2007). Menurut Francis dan Schipper (1999), angka-angka dalam laporan keuangan dikatakan memiliki relevansi nilai jika mempunyai hubungan (related) dengan harga saham. Barth, Landsman, dan Lang (2008) serta Chua, Cheong, dan Gould (2012) menjelaskan kualitas informasi akuntansi yang tinggi diindikasikan dengan adanya hubungan yang kuat antara harga saham dengan laba dan nilai buku ekuitas.Informasi akuntansi yang relevan akan membantu pengguna laporan keuangan dalam membuat prediksi tentang kejadian masa depan (Kieso, Weygandt, dan Warfield, 2014: 32).

Menurut Francis dan Schipper (1999) terdapat empat interpretasi konsep relevansi nilai, yaitu sebagai berikut:

a. Interpretasi pertama menyatakan bahwa informasi laporan keuangan menunjukkan harga saham dengan menangkap nilai intrinsik saham terhadap pergerakan harga saham. 
b. Interpretasi kedua menyatakan bahwa informasi keuangan memiliki relevansi nilai apabila mengandung variabel-variabel yang digunakan dalam model penilaian (valuation model) atau membantu dalam memprediksi variabel-variabel tersebut.

c. Interpretasi ketiga menyatakan bahwa relevansi nilai dilihat dari adanya hubungan statistik yang mengukur apakah investor benar-benar menggunakan informasi keuangan dalam penetapan harga saham. Sehingga, relevansi nilai diukur dengan kemampuan informasi laporan keuangan dalam mengubah harga saham.

d. Interpretasi keempat menyatakan bahwa relevansi nilai diukur dengan kemampuan informasi laporan keuangan dalam menangkap informasi tanpa memandang sumbernya, yang dapat mempengaruhi harga saham. Interpretasi ini tidak menuntut laporan keuangan harus menjadi sumber informasi paling awal.

a. Interpretasi ketiga dan keempat dari relevansi nilai diindikasikan dengan hubungan statistik antara informasi akuntansi dengan nilai pasar modal yang berupa harga saham atau return saham.

Penelitian ini menggunakan interpretasi relevansi nilai yang dikaitkan dengan hubungan statistik antara harga saham dengan laba per saham dan nilai buku ekuitas pada interpretasi ketiga. Laba per saham mewakili informasi laporan keuangan, sedangkan nilai pasar modal yang digunakan adalah harga saham.

\subsection{Harga Pasar Saham}

Harga pasar saham mencerminkan nilai saham suatu perusahaan yang mengalami kenaikan atau penurunan sesuai dengan likuiditas saham bersangkutan (Hadi, 2013: 72). Harga yang terjadi pasar sekunder dipandang sebagai harga yang benar-benar mewakili nilai perusahaan, sebab dipasar sekunder kecil sekali kemungkinan terjadi negosiasi harga antara investor dengan perusahaan penerbit.

Harga pasar saham yang dapat digunakan sebagai informasi relevan suatu perusahaan adalah harga pasar saham setelah laporan keuangan hasil audit diterbitkan (Karunarathne dan Rajapakse, 2010).

\subsection{Nilai Buku Ekuitas}

Komponen ekuitas pemegang saham menurut Suwardjono (2012) adalah modal setoran dan saldo laba. Pada dasarnya ekuitas merupakan salah satu bentuk pencatatan akuntansi yang dapat mencerminkan besarnya nilai yang dimiliki oleh pemegang saham jika semua aset dilikuidasi dan dikurangi dengan kewajiban (Widiastuti dan Meiden, 2013).

Menurut Ohlson (1995), nilai buku ekuitas merupakan proksi atas future normal earnings yang diharapkan dari perusahaan. Burgstahler dan Dichev (1997) menyatakan bahwa relevansi nilai buku ekuitas berasal dari perannya sebagai suatu proksi untuk nilai adaptasi dan nilai penolakan. Nilai buku (book value) ekuitas per lembar saham dapat diperoleh dari total ekuitas dibagi dengan jumlah saham beredar (Kieso, Weygandt, dan Warfield, 2014: 729).

\subsection{Laba Per Saham}

Laba per saham adalah jumlah laba yang tersedia untuk setiap saham ekuitas (I AI, 2014: 56.3) yang dihitung dengan membagi laba bersih dengan jumlah saham yang beredar dalam suatu periode. Menurut Kieso (2014: 770), laba per saham menunjukkan laba yang dihasilkan oleh setiap lembar saham biasa. Umumnya informasi tentang laba per saham dilaporkan di bawah laba bersih dalam laporan laba rugi.

\subsection{Konvergensi IFRS di Indonesia dan Perkembangan PSAK}

IFRS merupakan standar akuntansi internasional yang dibuat oleh International Accounting Standard Board (IASB). IAI sebagai organisasi profesi menyusun standar akuntansi di Indonesia sejak tahun 1994 telah melakukan adaptasi dan harmonisasi standar akuntansi internasional (Wulandari, 2014). Indonesia sudah melakukan konvergensi IFRS secara bertahap sejak tahun 2008 dan target penerapan penuh IFRS dapat diselesaikan pada tahun 2012. 
Berbagai penelitian mengenai pengaruh penerapan SAK berbasis IFRS terhadap laporan keuangan perusahaan/emiten telah dilaksanakan oleh peneliti terdahulu. Penelitian ini didasarkan pada berbagai kendala yang dihadapi oleh para emiten di dalam penerapan SAK berbasis IFRS dari sudut pandang kemanfaatannya bagi emiten, khususnya tentang apakah terdapat efisiensi setelah penerapannya. Sesungguhnya berbagai penelitian telah dilakukan sebelumnya tentang relevansi nilai setelah periode penerapan IFRS menyatakan bahwa terdapat peningkatan hubungan antara harga pasar saham dengan nilai buku ekuitas dan laba tetapi dengan hasil yang berbeda-beda. Iatridis (2010) menemukan bahwa pada periode setelah adopsi IFRS terdapat peningkatan relevansi nilai dari nilai buku ekuitas dan laba per saham terhadap harga pasar saham pada perusahaan yang tercatat di Bursa Efek London. Sementara Kargin (2013) menemukan bahwa setelah penerapan IFRS terdapat peningkatan relevansi nilai dari nilai buku ekuitas, namun tidak ada peningkatan relevansi nilai atas laba per saham pada perusahaan yang terdaftar di Bursa Efek Istanbul selama tahun 1998-2011. Chalmers, Clinch, dan Godfrey (2011) menemukan hasil yang berbeda, bahwa setelah penerapan IFRS terdapat peningkatan relevansi nilai terhadap laba per saham, sementara relevansi nilai dari nilai buku ekuitas tidak ada peningkatan pada perusahaan yang terdaftar di Australian Securities Exchange selama tahun 1990-2008. Kwong (2010) menemukan bahwa terdapat peningkatan relevansi nilai dari nilai buku ekuitas dan laba per saham terhadap harga pasar saham setelah periode penerapan IFRS

Hasil penelitian Khanagha (2011) serta Kousenidis, Lades, dan Negakis (2010) menunjukkan bahwa relevansi nilai laba dan nilai buku ekuitas mengalami penurunan setelah periode penerapan IFRS. Outa (2011) menemukan bahwa tidak terdapat peningkatan relevansi nilai dari nilai buku ekuitas dan laba per saham terhadap harga pasar saham setelah periode penerapan IFRS pada perusahaan yang terdaftar Nairobi Stock Exchange selama tahun 19952004.

Penelitian tentang peningkatan relevansi nilai setelah penerapan IFRS pada perusahaan yang terdaftar di Bursa Efek Indonesia juga menemukan hasil yang berbeda-beda. Suprihatin dan Tresnaningsih (2013) menyatakan bahwa pada awal penerapan IFRS laba per saham mengalami peningkatan dalam relevansi nilai, sedangkan nilai buku ekuitas tidak meningkat. Tetapi pada tahap lanjut penerapan IFRS, relevansi nilai untuk laba per saham dan nilai buku ekuitas mengalami peningkatan. Sementara Cahyonowati dan Ratmono (2012) menyatakan bahwa tidak terdapat peningkatan relevansi nilai laba dan nilai buku ekuitas secara keseluruhan setelah periode adopsi IFRS.

\subsection{Kerangka Pemikiran}

Penelitian ini menggunakan interpretasi relevansi nilai yang menyatakan bahwa terdapat hubungan antara nilai buku ekuitas dan laba per saham terhadap harga pasar saham (Francis dan Schipper, 1999). Di dalam penelitian ini variabel dependen yang digunakan adalah harga pasar saham (Y), sedangkan variabel independen yang digunakan adalah nilai buku ekuitas (X1) dan laba per saham (X2). Periode pengujian dalam penelitian ini terbagi menjadi dua, yaitu pada periode sebelum penerapan SAK berbasis IFRS dan periode sesudah penerapan SAK berbasis IFRS. Tahun 2008-2010 digunakan sebagai periode sebelum penerapan SAK berbasis IFRS. Tahun 2012-2014 digunakan sebagai periode sesudah penerapan SAK berbasis IFRS. Kerangka pemikiran dalam penelitian ini adalah sebagai berikut: 


\section{Kerangka Pemikiran}

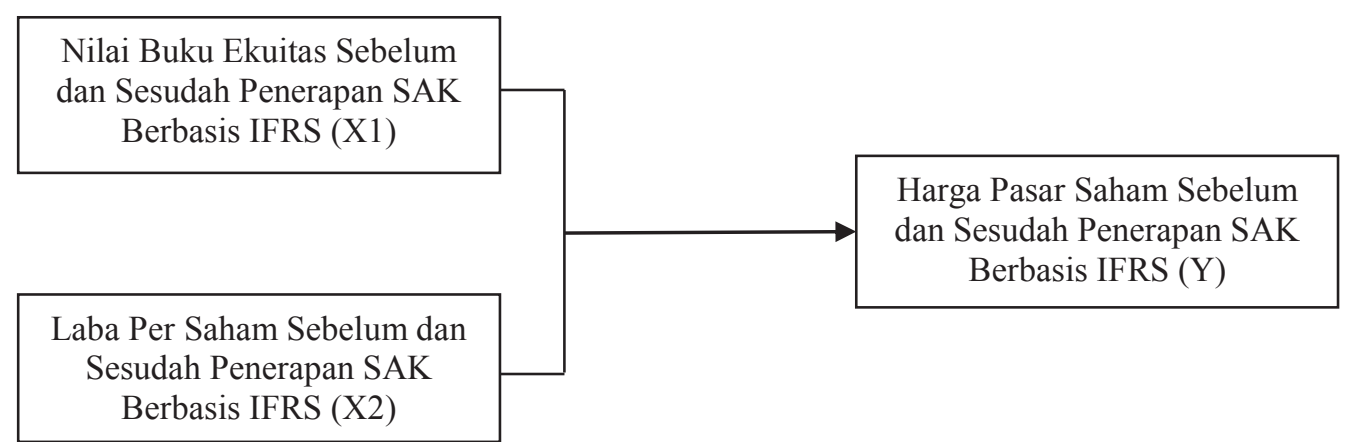

\subsection{Perumusan Hipotesis}

Pengunaan IFRS dapat meningkatkan keakuratan dalam menilai kinerja perusahaan dibuktikan oleh hasil penelitian yang dilakukan oleh Asbaugh dan Pincus (2001), yang menyatakan bahwa keakuratan analisis yang dilakukan oleh para analisa keuangan meningkat setelah perusahaan mengadopsi atau menggunakan IFRS. Pelaporan keuangan menggunakan IFRS dengan fair value juga menyediakan informasi yang lebih berguna bagi investor, karena lebih mencerminkan kondisi ekonomik perusahaan (Barth, Landsman, dan Lang, 2008).

Adanya peningkatan relevansi nilai laba dan nilai buku ekuitas setelah penerapan IFRS ditemukan pada sebagian besar penelitian yang dilakukan di berbagai negara, antara lain Australia (Chalmers, Clinch, dan Godfrey, 2011), Inggris (Iatridis, 2010) dan Turki (Kargin, 2013). Penelitian yang dilakukan di Indonesia oleh Suprihatin dan Tresnaningsih (2013) juga menunjukkan adanya peningkatan relevansi nilai laba dan nilai buku ekuitas setelah penerapan IFRS pada PSAK.

Penerapan IFRS diharapkan akan meningkatkan fungsi pasar modal global dengan menyediakan informasi yang lebih dapat diperbandingkan dan berkualitas tinggi kepada investor (Barth, 2008). Selain itu IFRS juga diharapkan dapat memberikan informasi keuangan yang lebih akurat, komprehensif dan tepat waktu dibandingkan standar akuntansi nasional yang banyak dipengaruhi oleh hukum negara, politik, dan perpajakan di negara tersebut (Ball, 2006). Untuk itu dihipotesiskan bahwa:

$\mathrm{H}_{1}$ : Secara rata-rata, relevansi nilai dari nilai buku ekuitas terhadap harga saham akan meningkat pada periode sesudah penerapan SAK berbasis IFRS dibandingkan sebelum penerapan SAK berbasis IFRS.

$\mathrm{H}_{2}$ : Secara rata-rata, relevansi nilai dari laba per saham terhadap harga saham akan meningkat pada periode sesudah penerapan SAK berbasis IFRS dibandingkan sebelum penerapan SAK berbasis IFRS.

\section{METODE PENELITIAN}

Jenis penelitian ini adalah penelitian deskriptif kuantitatif yang dilakukan dengan mengumpulkan data yang menjelaskan karakteristik dari seseorang, peristiwa atau situasi Sekaran (2014). Penelitian ini bertujuan untuk menemukan bukti empiris tentang pengaruh penerapan SAK berbasis IFRS terhadap relevansi nilai dari nilai buku ekuitas dan laba per saham terhadap harga pasar saham pada perusahaan manufaktur yang terdaftar di BEI selama tahun 2008-2010 dan 2012-2014.

\subsection{Operasionalisasi Variabel}

Operasional variabel menunjukkan variabel-variabel yang digunakan dalam penelitian ini. Variabel yang digunakan dalam penelitian ini adalah sebagai berikut:

1. Harga Pasar Saham (PRICE)

Harga pasar saham dapat merepresentasikan penilaian investor dan informasi yang relevan terkait dengan perusahaan (Houlthasen dan Watts, 2001). 
2. Nilai Buku Ekuitas (BVPS)

Variabel nilai buku ekuitas (BVPS) diukur dengan nilai buku ekuitas per saham. Nilai buku ekuitas dapat dihitung dengan rumus sebagai berikut (Kieso 2014: 729):

$$
\mathrm{BVPS}=\frac{\text { Ordinary Shareholders' Equity }}{\text { Outstanding Shares }}
$$

3. Laba Per Saham (EPS)

Perhitungan laba per saham (EPS) diperoleh dengan rumus sebagai berikut (Kieso 2014: 771):

$$
\mathrm{EPS}=\frac{\text { Net Income }- \text { Preference Dividends }}{\text { Weighted Average of Outstanding Shares }}
$$

\subsection{Populasi dan Sampel}

Populasi yang diamati adalah seluruh perusahaan yang terdaftar di BEI selama tahun 2008-2010 dan 2012-2014 karena emiten tersebut dipandang sebagai perusahaan dengan akuntabilitas signifikan yang diwajibkan menggunakan SAK berbasis IFRS dalam penyusunan laporan keuangannya (Cahyonowati dan Ratmono, 2012). Sampel yang digunakan adalah perusahaan yang bergerak dalam bidang manufaktur karena merupakan perusahaan yang paling banyak yaitu 142 emiten dari 507 yang terdaftar di BEI.

\subsection{Jenis dan Sumber Data}

Penelitian ini menggunakan jenis data sekunder yang berupa laporan keuangan perusahaan manufaktur yang terdaftar di BEI selama tahun 2008-2010 dan 2012-2014. Sumber data sekunder dalam penelitian ini diperoleh dari website www.idx.co.id dan finance.yahoo.com

\subsection{Metode Pengumpulan Data}

Pengumpulan data dilakukan melalui metode observasi nonpartisipan. Menurut Sugiyono (2010: 204), metode observasi nonpartisipan adalah metode yang digunakan peneliti jika peneliti tidak terlibat langsung dengan aktivitas-aktivitas yang sedang diamati dan hanya sebagai pengamat independen. Data variabel harga pasar saham diperoleh dengan cara mengutip secara langsung dari website finance.yahoo.com, sedangkan data variabel laba per saham dan nilai buku ekuitas diperoleh dengan cara mengutip langsung dari laporan keuangan triwulan yang tersedia di website www.idx.co.id dan www.icamel.id selama tahun 2008-2010 dan 2012-2014.

\section{HASIL PENELITIAN DAN PEMBAHASAN}

Berdasarkan kriteria yang sudah ditetapkan, jumlah entitas yang dijadikan sampel sebanyak 51 perusahaan. Pemilihan sampel dilakukan menggunakan metode purposive sampling, yaitu sampel yang harus memenuhi kriteria tertentu. Periode pengamata adalah 3 tahun, dengan demikian jumlah pengamatan sebanyak 153.Berdasarkan kriteria pemilihan sampel, diperoleh jumlah pengamatan sebanyak 153 .

\subsection{Analisis Statistik}

Hasil analisis statistik deskriptif atas variabel-variabel yang digunakan dalam penelitian disajikan untuk masing-masing periode penerapan SAK berbasis IFRS adalah sebagaimana terdapat dalam Tabel 1 berikut: 
Tabel 1 Statistik Deskriptif Variabel Model Penelitian

\begin{tabular}{llrr}
\hline Variabel & \multicolumn{1}{c}{ Statistik Deskriptif } & \multicolumn{1}{c}{ Sebelum } & \multicolumn{1}{c}{ Sesudah } \\
\hline \multirow{4}{*}{ PRICE } & Minimum & 0,32 & 50 \\
& Maximum & $34.032,15$ & $61.553,63$ \\
& Mean & $1.685,64$ & $5.681,62$ \\
& Std. Deviation & $4.250,66$ & $11.656,47$ \\
\hline \multirow{5}{*}{ BVPS } & Minimum & 14,5 & 44,72 \\
& Maximum & $36.858,77$ & $47.740,25$ \\
& Mean & $3.757,35$ & $4.661,75$ \\
& Std. Deviation & $7.167,36$ & $9.538,10$ \\
\hline \multirow{5}{*}{ EPS } & Minimum & 1,13 & 0.19 \\
& Maximum & 25.098 & 46.017 \\
& Mean & $1.558,87$ & 1.756 .95 \\
& Std. Deviation & $4.010,71$ & 5.810 .85
\end{tabular}

Sumber: Output program Stata yang diolah

Dari tabel terlihat bahwa rata-rata PRICE pada periode sebelum penerapan SAK berbasis IFRS adalah 1.685,64 dengan variasi nilai minimum 0,32 dan nilai maksimum 34.032,15. PRICE pada periode sesudah penerapan SAK berbasis IFRS memiliki rata-rata yang lebih tinggi yaitu sebesar 5.681,62 dengan nilai simpangan baku yang lebih lebar, yaitu nilai minimum 50 dan nilai maksimum 61.553,63. Peningkatan nilai rata-rata dan nilai maksimum PRICE pada periode sebelum dan sesudah penerapan SAK berbasis IFRS menunjukkan bahwa terdapat peningkatan harga saham yang cukup signifikan pada periode tersebut dengan besarnya peningkatan harga saham tidak merata bagi semua perusahaan.

Nilai buku ekuitas (BVPS) pada periode sebelum penerapan SAK berbasis IFRS memiliki ratarata sebesar 3.757,35 dengan nilai minimum sebesar 14,5 dan nilai maksimum sebesar 36.858,77 yang menunjukkan variasi BVPS yang besar. Pada periode sesudah penerapan SAK berbasis IFRS, nilai rata-rata BVPS adalah 4.661,75 dengan nilai minimum sebesar 44,72 dan nilai maksimum 47.740,25 serta standar deviasi sebesar 9.538,10 yang menunjukkan simpangan baku yang bervariasi. Hasil ini menunjukkan bahwa nilai buku ekuitas pada seluruh perusahaan pada periode sebelum dan sesudah penerapan SAK berbasis IFRS mengalami pertumbuhan dengan besaran yang tidak merata.

Nilai EPS menunjukkan bahwa pada periode sebelum penerapan SAK berbasis IFRS memiliki rata-rata 1.558,87 dengan variasi simpangan baku yang lebar, yaitu nilai minimum sebesar 5,04 dan nilai maksimum sebesar 25.098. EPS pada periode sesudah penerapan SAK berbasis IFRS memiliki rata-rata yang lebih tinggi yaitu sebesar 46.017 dengan nilai variasi simpangan baku yang lebar, yaitu nilai minimum sebesar 0.19 dan nilai maksimum sebesar 46.017. Hasil statistik deskriptif ini menunjukkan bahwa laba per saham pada seluruh perusahaan pada periode sebelum dan sesudah penerapan SAK berbasis IFRS mengalami pertumbuhan yang cukup besar, namun besarnya pertumbuhan tidak cukup merata bagi semua perusahaan.

\section{Pemilihan Model Estimasi dalam Analisis Data Panel}

Untuk menetapkan metode estimasi yang paling tepat untuk model regresi yang menggunakan data panel, dilakukan pengujian dengan Chow Test, Hausman Test, dan Lagrange Multiplier Test. Hasil pengujian disajikan berikut ini:

Tabel 2. Pemilihan Model Regresi Data Panel

\begin{tabular}{lll}
\hline \multicolumn{1}{c}{ Nama Uji } & \multicolumn{1}{c}{ Hasil Model Sebelum } & \multicolumn{1}{c}{ Hasil Model Sesudah } \\
\hline Chow Test & Prob $>\mathrm{F}=0,0000$ & Prob $>\mathrm{F}=0,0000$ \\
& p-value $<0,05$ & p-value $<0,05$ \\
\hline Hausman Test & Prob $>$ chi $2=0,5269$ & Prob $>$ chi2 $=0,6475$ \\
& p-value $<0,05$ & p-value $<0,05$ \\
\hline
\end{tabular}




\begin{tabular}{lll}
\hline Lagrange Multiplier Test & Prob $>$ chi2 $=0,0000$ & Prob $>$ chi2 $=0,0000$ \\
& $p$-value $<0,05$ & $p$-value $<0,05$ \\
\hline Kesimpulan & Model penelitian akan & Model penelitian akan \\
& diujikan sebagai model diujikan sebagai model \\
& Random Effect (RE) & Random Effect (RE) \\
\hline
\end{tabular}

Sumber: Output program Stata yang diolah

Chow test digunakan untuk menentukan apakah suatu model statistik penelitian pada data panel lebih tepat menggunakan metode Pooled Least Square (PLS) atau Fixed Effect (FE). Hasil Chow test untuk model sebelum penerapan SAK berbasis IFRS menunjukkan bahwa nilai $p$ value dari F-stat maupun chi-square lebih kecil daripada alpha $5 \%$. Hasil tersebut menunjukkan bahwa model penelitian lebih baik menggunakan metode pengujian dengan model Fixed Effect (FE). Sementara itu, hasil Chow test untuk model sesudah penerapan SAK berbasis IFRS menunjukkan bahwa nilai $p$-value dari F-stat maupun chi-square lebih kecil daripada alpha $5 \%$. Hasil tersebut menunjukkan bahwa model penelitian lebih baik menggunakan metode pengujian dengan model Fixed Effect (FE).

Hausman test yang digunakan untuk menentukan apakah suatu model statistik penelitian pada data panel lebih tepat menggunakan metode Fixed Effect (FE) atau Random Effect (RE). Hasil Hausman test untuk model sebelum penerapan SAK berbasis IFRS menunjukkan bahwa nilai p-value dari chi-square lebih besar dari alpha 5\%. Hasil tersebut menunjukkan bahwa model penelitian lebih baik menggunakan metode pengujian dengan model Random Effect (RE). Sementara itu, hasil Hausman test untuk model sesudah penerapan SAK berbasis IFRS menunjukkan bahwa nilai p-value dari chi-square lebih besar dari alpha 5\%. Hasil tersebut menunjukkan bahwa model penelitian lebih baik menggunakan metode pengujian dengan model Random Effect (RE).

Lagrange Multiplier test yang digunakan untuk menentukan apakah suatu model statistik penelitian pada data panel lebih tepat menggunakan metode Pooled Least Squares (PLS) atau Random Effect (RE). Hasil Lagrange Multiplier test untuk model sebelum penerapan SAK berbasis IFRS menunjukkan bahwa nilai p-value dari chi-square lebih kecil dari alpha 5\%. Hasil tersebut menunjukkan bahwa model penelitian lebih baik menggunakan metode pengujian dengan model Random Effect (RE). Sementara itu, hasil Lagrange Multiplier test untuk model sesudah penerapan SAK berbasis IFRS menunjukkan bahwa nilai $p$-value dari chi-square lebih kecil dari alpha 5\%. Hasil tersebut menunjukkan bahwa model penelitian lebih baik menggunakan metode pengujian dengan model Random Effect (RE).

Kesimpulan dari ketiga pengujian tersebut adalah pemilihan model statistik untuk periode sebelum dan sesudah penerapan SAK berbasis IFRS lebih tepat diuji dengan model Random Effect (RE).

\section{Hasil Pengujian Asumsi Klasik}

Sebelum menganalisis hasil regresi, dilakukan uji asumsi klasik untuk memastikan bahwa hasil regresi memenuhi asumsi dasar ekonometrika yaitu asumsi Best Linear Unbiased Estimator (BLUE) di mana sebuah model statistik data panel harus diuji apakah terdapat permasalahan multikolinearitas, heteroskedastisitas, dan autokorelasi. Pengujian tersebut untuk menghasilkan suatu persamaan regresi yang linear, tidak bias, dan efisien (Widarjono, 2013: 99).

Dalam penelitian ini hanya dilakukan pengujian multikolinearitas, karena pemilihan model penelitian untuk periode sebelum dan sesudah penerapan SAK berbasis IFRS menggunakan model Random Effect (RE) untuk data panel, sesuai dengan hasil pengujian pemilihan model regresi di atas. Menurut Gujarati (2004: 647-649), model Random Effect (RE) menggunakan estimasi Generalized Least Squares (GLS), di mana error term dalam model Random Effect adalah homoscedastic, yang berarti model sudah terbebas dari masalah heteroskedastisitas, dan individual error component tidak berkolerasi dengan individu lainnya dan tidak ada 
autocorrelated across individu antara cross-section dan time-series, yang berarti model sudah terbebas dari masalah autokorelasi.

\section{Uji Multikolinieritas}

Hasil pengujian multikolinearitas dilakukan terhadap model penelitian yang disajikan di bawah ini:

Tabel 3. Hasil Uji Multikolinieritas

\begin{tabular}{ccccc}
\hline \multirow{2}{*}{ Variabel } & \multicolumn{2}{c}{ Sebelum } & \multicolumn{2}{c}{ Sesudah } \\
& Tolerance & VIF & Tolerance & VIF \\
\hline BVPS & 0,604 & 1,66 & 0,338 & 2,96 \\
\hline EPS & 0,604 & 1,66 & 0,338 & 2,96 \\
\hline
\end{tabular}

Sumber: Output program Stata yang diolah

Berdasarkan tabel di atas diperoleh nilai tolerance lebih besar dari 0,10 dan VIF untuk masing-masing variabel tidak lebih dari 10 , baik untuk model sebelum ataupun sesudah penerapan SAK berbasis IFRS. Jadi dapat disimpulkan bahwa tidak ada multikolineritas antar variabel independen dalam model penelitian, baik untuk model sebelum ataupun sesudah penerapan SAK berbasis IFRS.

\section{Pengujian Regresi Model Penelitian}

Hasil pengujian regresi atas model penelitian yang merupakan pengujian atas pengaruh penerapan SAK berbasis IFRS dalam meningkatkan hubungan antara harga pasar saham dengan nilai buku ekuitas dan laba per saham disajikan sebagai berikut:

Tabel 4. Hasil Uji Regresi Model Penelitian

\begin{tabular}{|c|c|c|c|c|c|c|}
\hline \multirow{2}{*}{ Variabel } & \multicolumn{3}{|c|}{ Model Sebelum } & \multicolumn{3}{|c|}{ Model Sesudah } \\
\hline & Coeff. & $z$-stat & Prob & Coeff. & $z$-stat & Prob \\
\hline BVPS & 0.0631 & 0.97 & 0.1675 & 0,1525 & 2,25 & $0,013^{*}$ \\
\hline EPS & -0.0202 & -0.25 & 0.4005 & $-0,2526$ & $-3,15$ & $0,001 *$ \\
\hline R-squared & & 0,0106 & & & 0,0855 & \\
\hline Wald chi-square & & 0.94 & & & 9,96 & \\
\hline Prob (chi-square) & & 0,6261 & & & $0,0069^{*}$ & \\
\hline No. Observation & & 153 & & & 153 & \\
\hline
\end{tabular}

*signifikan pada alpha 5\%, Pengujian menggunakan one-tailed probability

Sumber: Output program Stata yang diolah

Dari di atas diperoleh persamaan regresi sebagai berikut:

Model periode sebelum penerapan SAK berbasis IFRS:

PRICE $=1.480,14+0,0631 \mathrm{BVPS}-0,0202 \mathrm{EPS}$

Model periode sesudah penerapan SAK berbasis IFRS:

PRICE $=5.414,31+0,1525 \mathrm{BVPS}-0,2526 \mathrm{EPS}$

\section{Uji Koefisien Determinasi $\left(R^{2}\right)$}

Sebagaimana terlihat pada tabel output regresi model penelitian di atas, model penelitian pada periode sebelum penerapan SAK berbasis IFRS memperoleh $R$-square sebesar 0,0106 yang berarti bahwa sekitar $1,06 \%$ variabel nilai harga saham perusahaan dapat dijelaskan oleh variabel nilai buku ekuitas dan laba perusahaan selama periode sebelum penerapan SAK berbasis IFRS. Sementara itu, model penelitian pada periode sesudah penerapan SAK berbasis IFRS memperoleh $R$-square sebesar 0,0855 yang berarti bahwa sekitar $8,55 \%$ variabel nilai harga saham perusahaan dapat dijelaskan oleh variabel nilai buku ekuitas dan laba perusahaan selama periode sesudah penerapan SAK berbasis IFRS. Hasil tersebut menunjukkan nilai Rsquare yang meningkat pada periode sesudah penerapan SAK berbasis IFRS, yang berarti bahwa penerapan SAK berbasis IFRS meningkatkan relevansi nilai dari nilai buku ekuitas dan laba per saham terhadap harga saham. 


\section{Uji Signifikan Simultan (Uji $F$ Statistik)}

Pada tabel tersebut terlihat nilai prob(chi-square) pada model penelitian periode sebelum penerapan SAK berbasis IFRS menunjukkan hasil yang tidak signifikan $(<0,05)$. Dengan demikian, dapat dikatakan bahwa variabel-variabel independen yang digunakan dalam model penelitian periode sebelum penerapan SAK berbasis IFRS secara bersama-sama tidak dapat menjelaskan variabel dependen secara signifikan.

Sementara itu, pada model penelitian periode sesudah penerapan SAK berbasis IFRS menunjukkan hasil yang signifikan $(<0,05)$. Dengan demikian, dapat dikatakan bahwa variabelvariabel independen yang digunakan dalam model penelitian periode sesudah penerapan SAK berbasis IFRS secara bersama-sama dapat menjelaskan variabel dependen secara signifikan.

\section{Uji Signifikansi Parsial (Uji $t$ Statistik)}

Program statistik Stata menggunakan analisis hipotesis two-tailed dalam output yang dihasilkan. Sementara hipotesis yang digunakan dalam penelitian menggunakan analisis hipotesis one-tailed, karena arah koefisien sudah ditentukan dalam hipotesis yang bahwa relevansi nilai buku ekuitas dan laba per saham akan meningkat sesudah penerapan SAK berbasis IFRS dalam menilai perusahaan. Oleh karena itu nilai probabilitas dalam output program Stata akan disesuaikan dengan one-tailed probability. Berikut ini adalah interpretasi masing masing variabel independen terhadap variabel dependen untuk model penelitian:

a. Variabel nilai buku ekuitas (BVPS) memiliki koefisien positif sebesar 0,0631 dan tidak signifikan pada periode sebelum penerapan SAK berbasis IFRS. Hal ini berarti nilai buku ekuitas (BVPS) tidak memiliki pengaruh yang signifikan terhadap harga pasar saham (PRICE) pada periode sebelum penerapan SAK berbasis IFRS. Pada periode sesudah penerapan SAK berbasis IFRS, variabel nilai buku ekuitas (BVPS) memiliki koefisien positif sebesar 0,1525 dan signifikan pada periode sesudah penerapan SAK berbasis IFRS. Hal ini berarti nilai buku ekuitas (BVPS) memiliki pengaruh positif yang signifikan terhadap harga pasar saham (PRICE) pada periode sebelum penerapan SAK berbasis IFRS pada periode sesudah penerapan SAK berbasis IFRS. Hal ini menunjukkan bahwa terjadi peningkatan relevansi nilai dari nilai buku ekuitas terhadap harga saham pada periode sesudah penerapan IFRS. Dengan demikian hipotesis 1 diterima. Hasil penelitian ini sejalan dengan Kargin (2013), yang menemukan bahwa relevansi nilai buku ekuitas mengalami peningkatan terhadap harga saham sesudah periode penerapan IFRS. Hal ini diduga bahwa penerapan SAK berbasis IFRS telah dipersepsikan oleh investor sebagai adanya peningkatan kualitas laporan keuangan, khususnya angka nilai buku ekuitas (Suprihatin dan Tresnaningsih, 2013).

b. Variabel laba per saham (EPS) memiliki koefisien negatif sebesar 0,0202 dan tidak signifikan pada periode sebelum penerapan SAK berbasis IFRS. Hal ini berarti nilai buku ekuitas (EPS) tidak memiliki pengaruh yang signifikan terhadap harga pasar saham (PRICE) pada periode sebelum penerapan SAK berbasis IFRS. Pada periode sesudah penerapan SAK berbasis IFRS, variabel laba per saham (EPS) memiliki koefisien negatif sebesar 0,2526 dan signifikan pada periode sesudah penerapan SAK berbasis IFRS. Hal ini berarti nilai buku ekuitas (BVPS) memiliki pengaruh negatif yang signifikan terhadap harga pasar saham (PRICE) pada periode sesudah penerapan SAK berbasis IFRS pada periode sesudah penerapan SAK berbasis IFRS. Hasil ini menunjukkan bahwa terjadi penurunan relevansi nilai dari nilai buku ekuitas terhadap harga saham pada periode sesudah penerapan IFRS. Dengan demikian hipotesis 2 ditolak. Hasil ini sejalan dengan penelitian Kousenidis, Lades, dan Negakis (2010). Hal ini diduga bahwa penerapan SAK berbasis IFRS tidak membawa perbaikan dalam relevansi nilai dari laba per saham dalam menilai harga saham (Khanagha, 2011).

\subsection{Pembahasan Hasil Penelitian}

Kargin (2013) menyatakan bahwa adopsi IFRS telah membawa perubahan terhadap relevansi nilai dari informasi akuntansi. Nilai relevansi tersebut dapat diukur dengan 
mengestimasi hubungan statistik antara nilai buku ekuitas dan laba per saham yang disajikan dalam laporan keuangan dengan harga pasar saham perusahaan. Menurut Suprihatin dan Tresnaningsih (2013), penerapan IFRS diklaim akan meningkatkan kualitas laporan keuangan. Berdasarkan hal tersebut, maka dikembangkan hipotesis yang menduga bahwa penerapan SAK berbasis IFRS akan membawa peningkatan terhadap relevansi nilai buku ekuitas dan laba per saham dalam menilai perusahaan. Berikut adalah hasil pengujian hipotesis:

Hipotesis 1, yang menduga bahwa secara rata-rata relevansi nilai buku ekuitas terhadap harga pasar saham akan meningkat sesudah periode penerapan SAK berbasis IFRS, diterima. Hasil penelitian ini menunjukkan bahwa terjadi peningkatan relevansi nilai dari nilai buku ekuitas pada periode sesudah adopsi IFRS, tetapi tidak terjadi peningkatan relevansi nilai dari laba per saham sesudah adopsi IFRS. Hasil penelitian ini sejalan dengan penelitian Kargin (2013)

Dengan demikian patut diduga bahwa penerapan SAK berbasis IFRS telah dipersepsikan oleh investor sebagai adanya peningkatan kualitas laporan keuangan, khususnya angka nilai buku ekuitas (Suprihatin dan Tresnaningsih, 2013).

Hipotesis 2, yang menduga bahwa secara rata-rata relevansi nilai laba per saham terhadap harga pasar saham akan meningkat sesudah periode penerapan SAK berbasis IFRS, ditolak. Hasil pengujian hipotesis 2 sejalan dengan Kousenidis, Lades, dan Negakis (2010). Hal ini menunjukkan bahwa penerapan SAK berbasis IFRS tidak membawa perbaikan dalam relevansi nilai dari laba per saham dalam menilai harga saham.

\section{SIMPULAN DAN KETERBATASAN}

\subsection{Simpulan}

Berdasarkan hasil pengujian yang telah dilakukan, maka dapat disimpulkan sebagai berikut:

a. Relevansi nilai buku ekuitas terhadap harga pasar saham mengalami peningkatan pada periode sesudah penerapan SAK berbasis IFRS. Hasil ini konsisten dengan ditemukannya peningkatan dari kemampuan variabel nilai buku ekuitas dalam menjelaskan variabel harga pasar saham pada periode sesudah penerapan SAK berbasis IFRS.

b. Relevansi nilai laba per saham terhadap harga pasar saham mengalami penurunan pada periode sesudah penerapan SAK berbasis IFRS. Hasil ini konsisten dengan ditemukannya penurunan dari kemampuan variabel laba per saham dalam menjelaskan variabel harga pasar saham pada periode sesudah penerapan SAK berbasis IFRS.

\subsection{Keterbatasan}

Dalam penelitian ini terdapat beberapa keterbatasan yaitu sebagai berikut:

a. Penelitian ini hanya menggunakan model harga yang dikembangkan Ohlson (1995) untuk menguji relevansi nilai buku ekuitas dan laba per saham terhadap harga pasar saham, sedangkan ada beberapa model lain yang dapat digunakan.

b. Penelitian ini mengalami kesulitan dalam mengumpulkan data melalui website www.idx.co.id, karena banyak perusahaan manufaktur yang tidak menyajikan laporan keuangan triwulan selama periode penelitian di website www.idx.co.id.

c. Penelitian ini tidak memperhatikan dampak dari SAK berbasis IFRS yang diberlakukan pada tahun tertentu terhadap nilai buku ekuitas dan laba per saham.

\section{DAFTAR PUSTAKA}

Alali, F. A., \& Foote, P. S. (2012). The Value Relevance of International Financial Reporting Standards: Empirical Evidence in an Emerging Market. The International Journal of Accounting, 47, 85-108. 
Ashbaugh, H., \& Pincus, M. (2001). Domestic Accounting Standards, International Accounting Standards, and the Predictability of Earnings. Journal of Accounting Research, 39(3), 417-434.

Ashbaugh, H., \& Pincus, M. (2001). Domestic Accounting Stnadards, International Accounting Standards, and the Predictability of Earnings. Journal of Accounting Research, 39(3), 417-434.

Bae, K.-H., \& Jeong, S. W. (2007). The Value-relevance of Earnings and Book Value, Ownership Structure, and Business Group Affiliation: Evidence From Korean Business Groups. Journal of Business Finance and Accounting, 34(5-6), 740-766.

Ball, R. (2006). International Financial Reporting Standards (IFRS): Pros and Cons for Investors. Accounting and Business Research, 36(Special Issue), 5-27.

Ball, R., Kothari, S., \& Robin, A. (2000). The Effect of International Institutional Factors on Properties of Accounting Earnings. Journal of Accounting and Economics, 29(1), 1-51.

Ball, R., Robin, A., \& Wu, J. S. (2003). Incentives versus Standards: Properties of Accounting Income in Four East Asian Countries, and Implications for Acceptance of IAS. Journal of Accounting and Economics, 36, 253-270.

Barth, M. (2008). Global Financial Reporting: Implications for U.S. Academics. The Accounting Review, 83(5), 1159-1179.

Barth, M., Landsman, W., \& Lang, M. (2008). International Accounting Standards and Accounting Quality. Journal of Accounting Research, 46(3), 467-498.

Baum, C. F. (2001). Residual Diagnostics for Cross-Section Time Series Regression Models. The Stata Journal, 1(1), 101-104.

Bernard, V. (1995). The Feltham-Ohlson Framework: Implications for Empiricists. Contemporary Accounting Research, 11(2), 733-747.

Burgstahler, D., \& Dichev, I. (1997). Earnings, Adaption and Equity Value. The Accounting Review, 72(2), 187-215.

Cahyonowati, N., \& Ratmono, D. (2012). Adopsi IFRS dan Relevansi Nilai Informasi Akuntansi. Jurnal Akuntansi dan Keuangan, 14(2), 105-115.

Callao, S., Jarne, J. I., \& Lainez, J. A. (2007). Adoption of IFRS in Spain: Effect on the Comparability an Relevance of Financial Reporting. Journal of International Accounting, Auditing and Taxation, 16, 148-178.

Chalmers, K., Clinch, G., \& Godfrey, J. M. (2011). Changes in Value Relevance of Accounting Information upon IFRS Adoption: Evidence From Australia. Journal of Management, $36,151-173$.

Chua, Y. L., Cheong, C. S., \& Gould, G. (2012). The Impact Mandatory IFRS Adoption on Accounting Quality: Evidence from Australia. Journal of Accounting International Research, 11(1), 119-146.

Daske, H., Hail, L., Leuz, C., \& Verdi, R. S. (2008). Mandatory IFRS Reporting Around the World: Early Evidence on the Economic Consequences. Journal of Accounting Research, 46, 1085-1142.

Drukker, D. M. (2003). Testing for Serial Correlation in Linear Panel-Data Models. The Stata Journal, 3(2), 168-177. 
Francis, J., \& Shipper, K. (1999). Have Financial Statements Lost Their Relevance? Journal of Accounting Research, 37(2), 319-352.

Ghozali, I. (2011). Aplikasi Analisis Mulivariate dengan Program IBM SPSS 19 (5 ed.). Semarang: Badan Penerbit Universitas Diponegoro.

Gujarati D. (2004). Basic Econometrics (4 ed). The Mc Graw Hill Companies

Hadi, N. (2013). Pasar Modal: Acuan Teoritis dan Praktis Investasi di Instrumen Keuangan Pasar Modal. Yogyakarta: Graha Ilmu.

Holthausen, R., \& Watts, R. (2001). The Relevance of The Value-Relevance Literature for Financial Accounting Standard Setting. Journal of Accounting and Economics, 31(1-3), 3-75.

Iatridis, G. (2010). International Financial Reporting Standards and The Quality of Financial Statement Information. International Review of Financial Analysis, 19, 193-204.

Ikatan Akuntan Indonesia. (2014). Standar Akuntansi Keuangan Per 1 Januari 2015. Jakarta: Dewan Standar Akuntansi Keuangan Ikatan Akuntan Indonesia.

Indonesia Stock Exchange. (2015). IDX Fact Book. Retrieved from http://www.idx.co.id/id$\mathrm{id} /$ beranda/publikasi/factbook.aspx

Jensen, M. C., \& Meckling, W. H. (1976, October). Theory of the Firm: Managerial Behavior, Agency Costs and Ownership Structure. Journal of Financial Economics, 3(4), 305360 .

Kargin, S. (2013). The Impact of IFRS on The Value Relevance of Accounting. International Journal of Economics and Finance, 5(4), 71-80.

Karunarathne, W., \& Rajapakse, R. (2010). The Value Relevance of Financial Statements' Information: With Special Reference to The Listed Companies in Colombo Stock Exchange. International Conference on Business and Information (pp. 1-20). Kelaniya: University of Kelaniya.

Khanagha, J. B. (2011). Value Relevance of Accounting Information in the United Arab Emirates. International Journal of Economics an Financial Issues, 1(2), 33-45.

Kieso, D., Weygandt, J., \& Warfield, T. (2014). Intermediate Accounting: IFRS Edition (2nd ed.). New York: John Wiley \& Son, Inc.

Kontan. (2013, April 10). Laba Samsung Tugu merosot. Retrieved Oktober 20, 2015, from Kontan.co.id: http://keuangan.kontan.co.id/news/laba-samsung-tugu-merosot

Kousenidis, D., Ladas, A., \& Negakis, C. (2010). Value Relevance of Accounting Information in the Pre- and Post-IFRS Accounting Periods. European Research Studies, XIII(1), $145-154$.

Kwong, L. C. (2010). The Value Relevance of Financial Reporting in Malaysia: Evidence from Three Different Financial Reporting Periods. International Journal of Business and Accountancy, 1(1), 1-19.

Mackenzie, B., Coetsee, D., Njikizana, T., Selbst, E., Chamboko, R., Colyvas, B., \& Hanekom, B. (2014). WILEY 2014 Interpretation and Application of International Financial Reporting Standards. New Jersey: John Wiley \& Sons, Inc.

Martani, D., NPS, S. V., Wardhani, R., Farahmita, A., \& Tanujaya, E. (2012). Akuntansi Keuangan Menengah Berbasis PSAK. Jakarta: Salemba Empat. 
Ohlson, J. A. (1995). Earnings, Book Values, and Dividends in Equity Valuation. Contemporary Accounting Research, 11(2), 661-687.

Outa, E. R. (2011). The Impact of International Financial Reporting Standards (IFRS) Adoption on the Accounting Quality of Listed Companies in Kenya. International Journal of Accounting and Financial Reporting, 1(1), 212-241.

Paananen, M., \& Lin, C. (2009). The Development of Accounting Quality of IAS and IFRS over Time: The Case of Germany. Journal of International Accounting Research, 8(1), $31-55$.

Peraturan Bapepam No: X.K.2 Tentang Penyampaian Laporan Keuangan Berkala Emiten atau Perusahaan Publik. (2012). Retrieved from http://www.bapepam.go.id

Republika Online. (2012, September 5). Laba Bersih Turun, Inilah Permintaan Dahlan Iskan untuk PLN. Retrieved Oktober 20, 2015, from Republika Online: http://www.republika.co.id/berita/nasional/umum/12/09/04/m9tbcs-laba-bersih-turuninilah-permintaan-dahlan-iskan-untuk-pln

Rohmah, A., \& Yuni, R. (2013). Dampak Standar Akuntansi Keuangan (SAK) Pasca Adopsi IFRS Terhadap Relevansi Nilai dan Asimetri Informasi. Simposium Nasional Akuntansi XVI, 601-623.

Scott, W. R. (2009). Financial Accounting Theory (5th ed.). Toronto: Pearson Canada Inc.

Shima, K. M., \& Yang, D. C. (2012). Factors Affecting the Adoption of IFRS. International Journal of Business, 17(3), 276-298.

Sugiyono. (2010). Metode Penelitian Bisnis (Pendekatan Kuantitatif, Kualitatif, dan R\&D). Bandung: ALFABETA.

Suprihatin, S., \& Tresnaningsih, E. (2013). Dampak Konvergensi International Financial Reporting Standards Terhadap Nilai Relevan Informasi Akuntansi. Jurnal Akuntansi dan Keuangan Indonesia, 10(2), 171-183.

Suwardjono. (2012). Teori Akuntansi: Perekayasaan Pelaporan Keuangan (Ketiga ed.). Yogyakarta: BPFE-Yogyakarta.

Widarjono, A. (2013). Ekonometrika Pengantar dan Aplikasinya Disertai Panduan EViews (Keempat ed.). Yogyakarta: UPP STIM YKPN.

Widiastuti, N. E., \& Maiden, C. (2013). Relevansi Nilai Laba dan Buku Ekuitas Dengan Dimoderasi Oleh Aspek Perpajakan. Media Riset Akuntansi, 3(1), 105-122.

Widoatmodjo, S. (2012). Cara Sehat Investasi di Pasar Modal: Pengantar Menjadi Investor Profesional (Revisi ed.). Jakarta: PT Elex Media Komputindo.

Wulandari, R. T. (2014). Perubahan Value Relevance dalam Informasi Akuntansi Setelah Adopsi IFRS: Bukti Perusahaan Manufaktur yang Terdaftar di Bursa Efek Indonesia (BEI). Simposium Nasional Akuntansi XVII. 